\title{
DAMPAK INDUSTRI TERHADAP LINGKUNGAN DAN SOSIAL
}

Oleh: Ita Rustiati Ridwan*)

\begin{abstract}
Abstrak
Industri secara umum adalah kelompok bisnis tertentu yang memiliki teknik dan metode yang sama dalam menghasilkan laba. Karena itu, dampak secara ekonomi lebih dirasakan, pedahal masih terdapat akibat lain yang tidak hanya menguntungkan tetapi juga merugikan yang jarang diperhatikan. Dalam perencanaan ekonomi dan wilayah urban, kawasan industri adalah penggunaan lahan dan aktivitas ekonomi secara intensif yang berhubungan dengan manufakturisasi dan produksi

Berdirinya Industri tentu membawa dampak, baik itu bagi lingkungan hidup mapun lingkungan sosial. Beberapa Dampak tersebut diantaranya seperti mengurangi tingkat pengangguran, meningkatkan kesejahteraan masyarakat disekitar kawasan industri dan lain sebagainya. Bagi kehidupan sosial, industri cenderung membawa dampak positif, tapi bagi lingkungan hidup industri membawa banyak dampak negatif seperti pencemaran air, polusi udara dan lain sebagainya. Selain yang telah disebutkan tadi, dalam lingkungan sosial industri biasanya mendapat tuntutan sosial.
\end{abstract}

Kata kunci: Dampak industri, lingkungan, sosial.

*) Dra. Ita Rustiati Ridwan, adalah Dosen PGSD UPI - Serang Banten. 


\section{Pendahuluan}

Istilah industri sering digunakan bagi suatu bagian produksi ekonomi yang terfokus pada proses manufakturisasi tertentu yang harus memiliki permodalan yang besar sebelum bisa meraih keuntungan. Dalam kasus ini sebenarnya lebih tepat disebut industri besar. Sebagai contoh pada tahun 2004, bisnis jasa keuangan adalah industri terbesar di dunia dalam kategori pendapatan.

Industri sebagai tempat produksi yang mengolah bahan mentah menjadi bahan baku atau bahan siap pakai untuk memenuhi kebutuhan manusia, memang sangat dirasakan dampaknya. Keberadaannya sangat dibutuhkan sekali di zaman sekarang ini, tidak hanya untuk memenuhi tuntutan kebutuhan pokok tetapi juga tuntutan yang beragam.

Tuntutan sosial pada perusahaan muncul sebagai refleksi pertanggungan jawab dari perusahaan (social responsibility) pada seluruh stakeholder utamanya. Mereka terdiri dari karyawan, pembeli, investor/nasabah, pemerintah, masyarakat dan kelangsungan lingkungan hidup bagi generasi penerus. Tanggung jawab sosial ini didefinisikan sebagai: "The way in which a business behaves towards other groups or individuals in its social environment: customer, other business, employees and investors".

Dengan dipenuhinya kewajiban-kewajiban ini maka perusahaan telah melakukan kegiatannya secara berkelanjutan dan tidak merugikan kepentingan para stakeholdernya. Perusahaan dalam mencari laba diperbolehkan, tetapi jangan pula mengabaikan hak-hak yang terkandung dan dimiliki oleh konsumen, investor dan masyarakat.

\section{Tahapan munculnya Tuntutan Sosial}

Tuntutan sosial ini muncul sejak abad ke 19, yang kemudian berkembang sampai saat ini, dalam berbagai tahapan berikut ini: 
Entrepeneurial Era

a) Bisnis pada abad ke 19 ditandai dengan bangkitnya semangat kewirausahaan dan filosofi mekanisme pasar bebas yang dipelopori oleh pengusaha Morgan dan Vanderbilt.

b) Pada saat itu banyak terjadi pelanggaran pada hak-hak pekerja dan cara-cara berbisnis dengan baik.

c) Beberapa negara kemudian mulai mengeluarkan undang-undang yang membatasi kecurangan-kecurangan dalam praktek melakukan bisnis.

The Great Depression

a) Pada tahun 1930-an banyak pihak yang menuding bahwa kegagalan pasar didorong oleh adanya ketamakan dalam mengejar laba.

b) Sehingga mulai timbul kesadaran perlunya UU yang mengatur perlindungan pada pekerja, konsumen dan masyarakat.

The Era of Social Activism

a) Dimulai tahun 1960-1970 kalangan bisnis dituding berkolaborasi dengan pemerintah, seperti dalam memanfaatkan berbagai kesempatan bisnis yang merugikan masyarakat. Contoh yang paling menonjol adalah produksi rokok dan kolaborasi bisnis dengan adanya perang Vietnam.

b) Masyarakat kemudian menuntut adanya UU tentang pembatasan merokok dan UU tentang perlindungan lingkungan alam.

Contemporary Social Consciousnes

a) Sejak 1990 masuklah era kesadaran dari berbagai pihak perlunya bisnis memperhatikan tanggung sosial, yang didorong dari perkembangan globalisasi dan kerusakan lingkungan

b) Berbagai UU Lingkungan hidup dan perlunya CSR program segera mulai diperkenalkan

\section{Berbagai kasus Kerusakan Lingkungan Hidup dan Tuntutan Melestarikannya dengan Undang-Undang}

Berikut ini dikemukakan berbagai kasus kerusakan kualitas lingkungan hidup manusia di dunia. Kerusakan yang semakin parah dan 
membahayakan ini, menuntut dunia bisnis dan perusahaan untuk melakukan perbaikan dan memelihara kelestariannya di masa depan, seperti:

\section{Air Pollution}

$\mathrm{CO} 2$ yang dikeluarkan oleh otomotif di metropolitan area telah melewati batas ambang keselamatan. Polusi oleh pabrik-pabrik industri berat menyebabkan hujan asam yang merusak hutan. Peraturan menggunakan saringan udara, dan teknologi pengurangan emisi sulphur dikeluarkan.

\section{Water Pollution}

Banyak terjadi kasus industri membuang limbah-industri ke sungai, danau atau laut. Keracunan penghuni sungai dan laut semakin merajalela. Indirect impact pada manusia sebagian besar pemerintah kota negara industri mengeluarkan undang-undang kualitas air sungai. Larangan penggunaaan phosphat. Masih banyak proses dumping sisa oli mobil, air limbah rumahtangga dan deterjen.

\section{Land Pollution}

Dua isu utama yang dihadapi saat ini adalah: 1) bagaimana memulihkan kerusakan kualitas tanah yang tererosi oleh polusi dalam proses produksi yang dilakukan oleh perusahaan, dan 2) bagaimana mencegah kerusakan kualitas tanah, yaitu mengeluarkan berbagai kebijakan pemerintah yang efektif dalam membatasi limbah industri dan penanganan sampah kota.

Masalah utama dalam penanganan kerusakan akibat land pollution ini dihadapkan oleh kenyataan lapangan berikut ini:

a) Racun limbah industri umumnya berasal dari bahan kimia berbahaya dan sisa-sisa dari radioaktif

b) Di Amerika Serikat setiap pabrik setiap tahunnya menghasilkan sekitar 40-60 ton limbah.

c) Produk limbah tersebut tidak dapat dimusnakan

d) Perlu tempat khusus sebagai tempat pembuangan

e) Proses daur ulang kaleng, kertas, plastik, kaca dsb masih belum dilakukan secara masal. 


\section{Kewajiban yang Perlu Dilakukan oleh Pengusaha}

Secara umum telah banyak tulisan maupun himbauan yang perlu dilakukan oleh pengusaha dalam meminimalisir kerugian yang dialami konsumen, karyawan, investor, maupun kerusakan kualitas lingkungan hidup lebih lanjut. Beberapa rekaman sara-saran kewajiban-kewajiban yang perlu dilakukan perusahaan mencakup hal-hal berikut:

\section{Kewajiban Terhadap Konsumen:}

a) Konsumen memiliki hak untuk mendapatkan produk yang aman

b) Konsumen memiliki hak untuk mendapatkan informasi tentang spesifikasi produk yang dijual perusahaan, antara lain dengan mencantumkan labeling yang benar.

c) Konsumen memiliki hak untuk didengarkan, perusahaan dapat membuka kontak pelanggan melalui Kotak Pos.

d) Konsumen memiliki hak untuk dapat dapat memilih barang yang mereka beli

e) Kolusi dalam penetapan harga yang merugikan konsumen tidak dilakukan.

f) Kampanye iklan sering tidak dilakukan secara berlebihan.

g) Kampanye iklan diikuti oleh produksi dan distribusi produk sesuai dengan pesan-pesan iklan

h) Kampanye iklan perlu memperhatikan faktor berikut ini:

(1) Tidak menayangkan materi iklan yang menonjolkan anak-anak sedang merokok.

(2) Mencantumkan kandungan kalori lemah kolesterol dalam makanan, komponen vitamin, dan unsur-unsur minuman kesehatan.

(3) Menayangkan dengan gencar produk konsumsi yang tidak layak dan tidak halal untuk dikonsumsi.

(4) Tidak memberikan iming-iming hadiah jika membeli produk. 


\section{Kewajiban Terhadap Karyawan:}

a) Melakukan proses seleksi dan penempatan pegawai secara transparan dengan mengajak para calon pegawai dari sekitar komunitas untuk berpartisipasi

b) Memberikan posisi jabatan dan balas jasa gaji dan pengupahan, serta promosi jabatan tanpa memadang asal gender, suku bangsa, senioritas dan asal negara.

c) Mematuhi peraturan dan UU ketenagakerjaan yang dikeluarkan oleh Pemerintah

\section{Kewajiban Terhadap Investor:}

a) Meniadakan berbagai potensi kecurangan yang mungkin timbul di perusahaan terhadap investor.

b) Menghindari praktek membuat laporan keuangan yang disemir dan tidak sesuai dengan standar pelaporan akuntansi yang berlaku

c) Melakukan perbuatan ilegal seperti mengeluarkan cek kosong dan proses pencucian uang

d) Melakukan proses "insider trading" dalam menjual kertas berharga perusahaan.

e) Mematuhi ketentuan tentang GAAP (generally accepted accounting practices), ketentuan pasar modal bagi para emiten dan pedoman yang diberlakukan perusahaan

\section{Kewajiban Terhadap Masyarakat dan Lingkungan Hidup:}

a) Menjalankan program community social responsibility, khususnya yang berkaitan dengan pelestarian kualitas lingkungan hudup.

b) Memperhitungkan dampak lintas sektor dalam proses produksi memanfaatkan bahan baku alam secara berkelanjutan.

c) Menerapkan prinsip SIDEC, Sustainabilitas, Interdependence, Diversitas, Equity, Cohesion dalam memanajen pengelolaan dan pemanfaatan lingkungan alam.

d) Mengembangkan pola hidup "kekitaan" ketimbang "keakuan" 
e) Menghasilkan proses produksi dengan mengoptimalkan upaya renewable resources, daur ulang non-renewable resources, mengupayakan zero-waste clean technology; dan pemanfaatan tataruang dan proses produksi dengan sedikit limbah dan polusi.

\section{Dampak Industri terhadap Pembangunan Daerah}

Perkembangan industri sering dikaitkan dengan perkembangan suatu wilayah. Hal ini disebabkan oleh adanya efek multiplier dan inovasi yang ditimbulkan oleh kegiatan industri berinteraksi dengan potensi dan kendala.

Pertumbuhan industri di suatu wilayah, dalam kenyataannya belum tentu dapat dirasakan dampak positifnya oleh masyarakat di daerah tersebut, bila dalam kenyataannya pertumbuhan industri tersebut tidak memiliki keterkaitan dengan sektor ekonomi lokal, seperti yang dinyatakan oleh Irawan dan Suparmoko (1992) di dalam Utama (2002) yang terjadi di Pakanbaru dan Dumai dimana terdapat kegiatan yang padat modal seperti tambang minyak. Apa yang dihasilkan oleh perusahaan tersebut hanya semata-mata untuk ekspor dan hubungannya dengan dalam negeri hanya dalam bentuk pembayaran upah-upah buruh. Tidak adanya keterkaitan dengan kegiatan ekonomi lokal, sehingga menyebabkan daerah tersebut merupakan daerah kantong cacing (the foreign enclave).

Perkembangan sektor pertanian di Indonesia sampai saat ini cukup menggembirakan, namun tingkat pendapatan masyarakat dari usaha pertanian belum meningkat seperti yang diharapkan. Karena itu Pemerintah mencanangkan sasaran pembangunan di Indonesia harus mengacu kepada Lima Pilar Utama, yaitu: 1) pembangunan ekonomi berbasiskan kerakyatan; 2) pembinaan dan pengembangan sumberdaya manusia; 3) pembangunan kesehatan/olahraga; 4) pembangunan/kegiatan seni budaya; dan 5) pembangunan dalam rangka meningkatkan iman dan taqwa. Pembangunan ekonomi kerakyatan difokuskan kepada 
pemberdayaan petani terutama di pedesaan, nelayan, perajin, dan pengusaha industri kecil.

Setiap pembangunan yang dilaksanakan harus mengacu kepada lima pilar utama. Karena pembangunan daerah sangat ditentukan oleh potensi yang dimiliki oleh suatu daerah, maka kebijaksanaan yang dibuat oleh pemerintah harus mengacu kepada potensi daerah yang berpeluang untuk dikembangkan, khususnya sektor pertanian. Potensi tersebut antara lain: 1) tanaman hortikultura; 2) tanaman perkebunan; 3) usaha perikanan; 4) usaha peternakan; 5) usaha pertambangan; 6) sektor industri; dan 7) potensi keparawisataan. Pengembangan sektor pertanian dalam arti luas harus diarahkan kepada sistem agribisnis dan agroindustri, karena pendekatan ini akan dapat meningkatkan nilai tambah sektor pertanian, yang pada hakekatnya dapat meningkatkan pendapatan bagi pelaku-pelaku agribisnis dan agroindustri di daerah.

Untuk pembangunan ekonomi pedesaan pemerintah daerah telah mengembangkan sektor pertanian khususnya sub sektor perkebunan. Arah kebijaksanaan sektor perkebunan ini adalah melaksanakan perluasan areal perkebunan dengan menggunakan sistem perkebunan inti rakyat (PIR), program kredit koperasi primer untuk anggota (KKPA) serta memberikan kesempatan kepada perkebunan swasta. Sub sektor ini dapat menyerap tenaga kerja, menunjang program permukiman dan mobilitas penduduk serta meningkatkan produksi dalam negeri maupun ekspor nonmigas. Perkebunan yang banyak dikembangkan di Indonesia adalah perkebunan kelapa sawit, karet, dan kelapa. Misalnya di daerah Riau yaitu perkebunan kelapa sawit.

Pembangunan perkebunan kelapa sawit pada hakekatnya adalah pembangunan ekonomi yang berorientasi pedesaan. Sasaran pembangunan sektor perkebunan tersebut adalah dapat meningkatkan pendapatan masyarakat pedesaan. Dengan demikian jumlah masyarakat miskin terutama di pedesaan dapat dikurangi. Tujuan pokok proyek perkebunan yang dilaksanakan itu adalah : pertama, meningkatkan produktivitas kebun-kebun rakyat dengan cara penyuluhan teknologi baru 
pertanian kepada mereka dan kedua, menjadikan sistem perkebunan tersebut sebagai program pemerataan baik dari segi penduduk maupun sebagai pemerataan pembangunan.

Kawasan perkebunan telah menyebabkan munculnya sumbersumber pendapatan baru yang bervariasi. Sebelum dibukanya kawasan perkebunan di pedesaan, sampel mengungkapkan sumber pendapatan masyarakat relatif homogen, yakni menggantungkan hidupnya pada sektor primer, memanfaatkan sumberdaya alam yang tersedia seperti apa adanya tanpa penggunaan teknologi yang berarti. Data lapangan mengungkapkan pada umumnya masyarakat hidup dari sektor pertanian sebagai petani tanaman pangan (terutama palawija) dan perkebunan (karet). Pada masyarakat di sekitar aliran sungai mata pencaharian seharihari pada umumnya sebagai nelayan dan pencari kayu di hutan. Selain teknologi yang digunakan sangat sederhana dan monoton sifatnya tanpa pembaharuan (dari apa yang mampu dilakukan). Orientasi usahanya juga terbatas kepada pemenuhan kebutuhan keluarga untuk satu atau dua hari mendatang tanpa perencanaan pengembangan usaha yang jelas (subsisten).

Kegiatan pembangunan perkebunan telah menimbulkan mobilitas penduduk yang tinggi. Akibatnya di daerah-daerah sekitar pembangunan perkebunan muncul pusat-pusat pertumbuhan ekonomi di pedesaan. Kondisi ini menyebabkan meningkatnya daya beli masyarakat pedesaan, terutama terhadap kebutuhan rutin rumah tangga dan kebutuhan sarana produksi perkebunan kelapa sawit. Dari sisi kebutuhan rumah tangga rata-rata pengeluaran petani setiap bulannya sebesar Rp 1.183.288.

Apabila dikaji dari struktur biaya pengusahaan perkebunan kelapa sawit yang teknis operasionalnya dirancang lebih banyak menggunakan teknik manual, biaya yang berkaitan dengan tenaga kerja langsung serta tenaga teknis di lapangan memiliki porsi yang cukup besar. Berdasarkan hal tersebut, perputaran uang yang terjadi di lokasi dalam jangka panjang diperkirakan dapat merangsang pertumbuhan ekonomi di wilayah ini dengan tumbuhnya perdagangan dan jasa. Hal ini memberikan arti bahwa 
kegiatan perkebunan kelapa sawit di pedesaan menciptakan multiplier effect, terutama dalam lapangan pekerjaan dan peluang berusaha.

Suatu peluang usaha akan menjadi sumber pendapatan yang memberikan tambahan penghasilan kepada masyarakat jika mampu menangkap peluang usaha yang potensial dikembangkan menjadi suatu kegiatan usaha yang nyata. Dengan demikian kemampuan masyarakat memanfaatkan peluang yang ada akan dipengaruhi oleh kemampuan masyarakat dalam menangkap peluang itu sendiri. Hal kedua adalah kemampuan mengorganisir sumberdaya yang dimiliki sedemikian rupa sehingga peluang yang potensial menjadi usaha yang secara aktual dapat dioperasikan (Basri, 2003).

Dengan menggunakan rumus angka pengganda diperoleh nilai MPC $=0,8415$ dan nilai PSY $=0,7079$. Sehingga diperoleh angka pengganda sebesar 2,48. Nilai ini dapat memberikan arti bahwa setiap pembelanjaan oleh petani kelapa sawit di lokasi dan sekitarnya sebesar Rp 100, secara sinerjik menjadikan perputaran uang di lokasi tersebut dan sekitarnya sebesar $\mathrm{Rp} 248,00$ melalui bentukbentuk usaha baik riil maupun jasa.

Nilai-nilai tersebut diperoleh dengan dasar dan asumsi sebagai berikut:

- Persentase pendapatan petani sawit dibelanjakan di wilayah setempat (MPC) sekitar 84,15\%.

- Kebutuhan kegiatan perkebunan kelapa sawit yang dapat dipenuhi di wilayah setempat (PSY) sebesar 70, $97 \%$, antara lain:

(1) Kebutuhan peralatan pertanian ringan yang digunakan dalam kelola teknis diproyeksikan mampu dipenuhi oleh wilayah setempat.

(2) Pengadaan sarana prasarana penunjang yang disediakan oleh perusahaan perkebunan dan koperasi dapat dipenuhi oleh wilayah setempat.

Jadi dampak industri secara umum dapat berdampak berdampak positif maupun negatif, dintaranya: 
1) Dampak positif pembangunan industri:
a. menambah penhasilan penduduk
b. menghasilkan aneka barang
c. memperluas lapangan pekerjaan
d. mengurangi ketergantungan dengan Negara lain
e. memperbesar kegunaan bahan mentah
f. bertambahnya devisa Negara

2) Dampak negatif pembangunan industri:
a. terjadinya arus urbanisasi
b. terjadinya pencemaran lingkungan
c. adanya sifat konsumerisme
d. lahan pertanian semakin kurang
e. cara hidup masyarakat berubah
f. limbah industri menyebabkan polusi tanah
g. terjadinya peralihan mata pencaharian

\section{Daftar Pustaka}

E. Maryani. 1998. Geografi Ekonomi. Bandung: Jurusan Geografi UPI http://www.bunghatta.info/content.php?article.212 http://businessenvironment.wordpress.com/2007/04/30/kewajibanperusahaan-memenuhi-tuntutan-sosial/ http://id.wikipedia.org/wiki/Industri 